\title{
LEGISLATION OF THE EUROPEAN UNION RELATED TO MUNICIPAL WASTE AND ITS REFLECTION IN THE ASSOCIATION AGREEMENT WITH UKRAINE
}

\author{
J. ZICHA, PhD, senior lecturer \\ of the Faculty of Management and Economics \\ of Tomas Bata University \\ E-mail: zicha@utb.cz \\ L. GOLOVKO, PhD, associate professor, associate professor \\ of the Department of International Law and Comparative Law \\ of National University of Life and Environmental Sciences of Ukraine \\ E-mail:golovko_l@nubip.edu.ua
}

\begin{abstract}
Summary. Since signing the Association Agreement with the European Union on June 27, 2014, Ukraine has continued process of adaptation of its legislation in the field of waste management to European standards. According to Annex XXX to Chapter 6 of the Association Agreement, Ukraine should implement the following three Directives: Directive 2008/98/EC of the European parliament and of the Council of 19 November 2008 on waste and repealing certain Directives; Council Directive 1999/31EC of 26 April 1999 on the landfill of waste and Directive 2006/21/EC of the European parliament and of the Council of 15 March 2006 on the management of waste from extractive industries. The benefits for Ukraine after signing the Association Agreement are unconditional, but more important is to implement its provisions.

Taking part in the joint Ukraine-Czech Republicresearch and development project "EU Environmental Policy on Solid Domestic Waste Management and its Implementation in Ukraine and the Czech Republic» we have studied EU waste law, its principles and standards. The state of adaptation of Ukrainian legislation to the requirements of the European Union in the field of waste management has been investigated and some gaps in Ukrainian legislation have been found.
\end{abstract}

Keywords: EU waste policy, EU law, waste management, municipal waste, adaptation of legislation to EU law

\section{Introduction.}

Implementation of the EU waste policy in Ukraine demands obligatory coordination of organizational and legal aspects of governance that is crutial for its effective functioning. That is why it is important to study relevant EU legislation, its principles and standards make analysis of what Ukraine has done in order to adapt national legislation in the field of waste management and determine what else should be done yet.

180 | ISSN 2663-1350 «ПРАВО. ЛЮДИНА. ДОВКІЛЛЯ» | «LAW. HUMAN. ENVIRONMENT» Vol. 10, No 4, 2019 
The purpose of the article is an analysis of EU legislation in the field of waste management and the state of adaptation of Ukrainian legislation in this sphere to requirements of EU law.

As for the methodology of the research, the article was written within the joint Ukraine-Czech Republic R\&D project «EU Environmental Policyon Solid Domestic Waste Management and its Implementation in Ukraine and the Czech Republic») which is carried out at the Faculty of Management and Economicsof Tomas Bata University and Faculty of Law of the National University of Life and Environmental Sciences of Ukraine. The methods of comparative, analytical and logical analysis were used to study EU waste law and compare it with Ukrainian legislation in this sphere.

\section{Results.}

EU waste policy occupies an important place within the Union's environmental portfolio and it also has a long lineage, starting from the Commission's 1972 Communication on the EC Programme on Environment, where the focus was on reduction of waste generation and recycling. Since then, waste management has been recognised as a priority area in all EU Environmental Action Programmes. As a result of economic and technological development we are facing different types of waste which require prevention to avoid adverse environmental or human health impacts. Yet, waste should not only be associated with environmental pollution but should be recognized as a valuable resource (Kingston, Heyvaert \& Cavoski, 2017: 489-490).

Currently, EU waste law is one of the most extensively and comprehensively developed part of the environmental acquis that attempts to cover all activities that may generate waste. It tends to be highly technical and requires Member States to invest in developing waste management infrastructure and waste treatment technologies, and also to develop administrative capacities (Kingston, Heyvaert \& Cavoski, 2017: 491). We may distinguish several areas covered by the EU waste law. The general framework is provided by directives on waste (Directive 2008/98/EC, 2008) and on the landfill of waste (Council Directive 1999/31/EC, 1999), and by regulations on shipment of waste (Regulation (EC) No $1013 / 2006,2006)$ and on waste statistics (Regulation (EC) No 2150/2002, 2002). Specific rules for waste from consumer goods are set by directives on packaging (European Parliament and Council Directive 94/62/EC, 1994), light-weight plastic bags (Directive (EU) 2015/720, 2015), end-of-life vehicles (Directive 2000/53/EC, 2000), type-approval of motor vehicles (Directive 2005/64/ EC, 2005), baterries and accumulators (Directive 2006/66/EC, 2006), or electrical and electronic equipment (Directive 2012/19/EU, 2012). Another set of provisions is focused on waste which is generated within specific activities, such as agriculture (Council Directive 86/278/ EEC, 1986), extractive industries (Directive $2006 / 21 / \mathrm{EC}, 2006$ ) or ship transportation (Directive 2000/59/EC, 2000). Special attention is paid also to transboundary movement of hazardous waste and its international legal framework set by the Basel Convention (The Basel Convention on the Control, 1999). In the framework of Euratom is also regulated radioactive waste and its shipments (Council Regulation (Euratom) No 1493/93, 1993) and management (Council Directive 2011/70/Euratom, 2011).

Vol. 10, No 4, 2019 «ПРАВО. ЛЮДИНА. ДОВКІЛЛЯ» | «LAW. HUMAN. ENVIRONMENT» ISSN 2663-1350| 181 
This overview is not complete as there are several others sources of EU waste law but it may provide general picture about the main topics.

Waste law has increasingly become a part of wider policy framework for sustainable consumption and production, and so-called circular economy. This has led to an increasing focus on reuse and recovery, but also on design and composition of products so as to minimise waste generation and make the substances that do become waste easier to turn into new products. In 2014 the Commission has presented a strategy called «Towards a circular economy: A zero waste programme for Europe». However, the new Commission withdrew the proposal, and in late 2015 has adopted «The Circular Economy Package», consisting of an action plan called «Closing the loop - An EU action plan for the Circular Economy» and six partly revised proposals for amending waste-related directives (Langlet \& Said Mahmoudi, 2016: 284). In March 2019, the Commission adopted a comprehensive report on the implementation of the Circular Economy Action Plan. The report presents the main achievements and sketches out future challenges to shaping our economy and paving the way towards a climate-neutral, circular economy where pressure on natural and freshwater resources as well as ecosystems is minimised (European Commission: Circular Economy).

Accorging to Annex XXX to Chapter 6 of the Association Agreement (Association Agreement between..., 2014), Ukraine undertakes to gradually approximate its legislation to the following EU legislation on waste and resource management within the stipulated timeframes (linked to date of the entry into force of the Agreement): a) Directive 2008/98/EC on waste:

- adoption of national legislation and designation of competent authority/ ies; preparation of waste management plans in line with the five-step waste hierarchy and of waste prevention programmes (3 years);

- establishment of full cost recovery mechanism in accordance with the polluter pays principle and extended producer responsibility principle; establishment of a permitting system for establishments/ undertakings carrying out disposal or recovery operations, with specific obligations for the management of hazardous wastes; establishment of a register of waste collection and transport establishments and undertakings (5 years);

b) Directive 1999/31/EC on the landfill of waste:

- adoption of national legislation and designation of competent authority/ies; classification of landfill sites; preparation of a national strategy reducing the amount of biodegradable municipal waste going to landfill; establishment of an application and permit system and of waste acceptance procedures; establishment of control and monitoring procedures in the operation phase of landfills and of closure and after-care procedures for landfills to be disaffected; establishment of conditioning plans for existing landfill sites; establishment of a costing mechanism; ensuring the relevant waste is subject to treatment before landfilling (6 years);

c) Directive 2006/21/EC on the management of waste from extractive industries:

- adoption of national legislation and designation of competent authority/ ies; establishment of a system to ensure that operators draw up waste management plans; establishment of a permit system, of financial guarantees and of an inspection system; establishment 
of procedures for the management and monitoring of excavation voids; establishment of closure and after-closure procedures for mining waste facilities; drawing up an inventory of closed mining waste facilities (5 years).

First steps to adapt domestic legislation to $\mathrm{EU}$ directives have been made (Ladychenko, Yara, Golovko \& Serediuk, 2019). On November 8, 2017, the Government approved the National Strategy for Waste Management in Ukraine until 2030. The strategy aims to introduce a systematic approach to waste management at the state and regional levels, reducing the volume of waste generation by increasing the volume of their recycling and reuse. Its implementation will be carried out in three stages: the first at period of 2017-2018, the second at period of 2019-2023, the third during years 2024-2030. Implementation of the Strategy is expected to facilitate the implementation of a waste management system on an innovative basis, the development of the relevant legislation, improvement of the state of the environment, as well as sanitary and epidemiological well-being of the population. It is also planned to attract investments in the field of waste management, and thus the creation of modern infrastructure, introduction of the latest technologies, reduction of burial of waste at the landfills, etc. In particular, the Strategy foresees the creation of 800 new facilities for the recycling of recycled materials, utilization and composting of biowaste by 2030 , reduction of the total amount of household waste disposal from $95 \%$ to $30 \%$, minimization of the total amount of buried waste from $50 \%$ to $35 \%$ by 2030 , and as well as the creation of a network of 50 regional landfills, meeting the requirements of the Directive 1999/31/EC on the landfill of waste. In the Strategy, it is also foreseen that an information system will operate to ensure the monitoring and control of waste management, which will include information on the nomenclature and the amount of waste that is generated, processed, recycled and disposed of. Business entities that provide such services will also be registered. An important instrument of control will be the creation of the National Register of Waste Sources, capacities in the field of their treatment and reporting system by business entities (Order of the Government..., 2017).

On January 1, 2018, the amendment to the Law of Ukraine "On Waste», which prohibits the disposal of unprocessed waste, came into force. According to the changes, bodies of local self-government are prohibited to bury unprocessed household waste at landfills, cities and villages should ensure sorting of garbage by types for recycling and disposal. In addition, the law provides that when local governments or local state administrations choose a sanitation scheme, preference should be given to proposals that provide for a greater degree of recycling or disposal of household waste. Thermal treatment of household waste is allowed only at specially designated enterprises or objects for this purpose. The incineration of household waste is allowed only for energy purposes in order to produce thermal and / or electrical energy. It is prohibited to design, construct and operate landfills for domestic waste without equipping groundwater protection systems and neutralizing biogas. These changes to the legislation in Ukraine were extremely necessary. However, the disadvantage is that the requirements of the new legislation are not being implemented in practice («On Waste», 1998).

Vol. 10, No 4, 2019 «ПРАВО. ЛЮДИНА. ДОВКІЛЛЯ»| «LAW. HUMAN. ENVIRONMENT» ISSN 2663-1350| 183 
At the same time, having analyzed the current legislation of Ukraine, we cannot observe significant progress in the sphere of waste management and household waste management in particular (Ladychenko \& Golovko, 2017; Ladychenko, Yara, Uliutina \& Golovko, 2019). First of all, it is necessary to adopt legislation that reflects the principles and basic requirements for waste management contained in the Waste Framework Directive or amend the existing legislation (Yara, Uliutina, Golovko \& Andrushchenko, 2018; Ladychenko \& Golovko, 2018). So far, no changes and additions have been made to the Law of Ukraine «On Waste» of March 5, 1998, which would expand and bring the law in line with terminology of the Directive 2008/98/EC on waste and which would establish rules on division of waste into three categories (hazardous, safe and inert), establish lists of operations for waste disposal and reflect other important provisions contained in the EU directive. No changes were made also to the Tax Code of Ukraine in the part of the environmental tax on waste disposal.So, despite the work which has been done so far, there is still no real adaptation of Ukrainian legislation to EU legislation in the field of waste management.

\section{Discussion.}

It is obvious that the Association Agreement covers only part of the EU waste legislation. However, due to the complexity of waste management, even this part may become a real challenge for proper transposition and implementation.

In Ukraine, the following problems in the sphere of handling domestic waste could be singled out: about half of landfills for solid wastes do not meet sanitary standards; the lack of a sufficient number of incineration plants; absence of obligatory sorting of household waste by the population; sanctions against persons who create spontaneous landfills are ineffective (significant number of unauthorized dumps are generated each year); insufficient stimulation of enterprises using secondary raw materials, low level of culture of the population in relation to the use of domestic waste, etc.

The way out of this situation is possible provided the joint work of the legislative and executive branches of power in Ukraine with a view to full and timely fulfillment of the obligations undertaken by Ukraine by signing the Association Agreement between Ukraine and the EU and the annexes to this Agreement. It is also necessary to create proper conditions for the operation of recycling waste materials business.

\section{References}

1. Kingston, S., Heyvaert, V. \& Cavoski, A. (2017). European Environmental Law. Cambridge: Cambridge University Press, 489-490.

2. Directive 2008/98/EC of the European Parliament and of the Council of 19 November 2008 On waste and repealing certain Directives. OJ L 312, 22.11.2008, 3-30.

3. Council Directive 1999/31/EC of 26 April 1999 On the landfill of waste. OJ L 182, 16.7.1999, 1-19.

4. Regulation (EC) No 1013/2006 of the European Parliament and of the Council of 14 June 2006 on shipments of waste. OJ L 190, 12.7.2006, 1-98.

5. Regulation (EC) No 2150/2002 of the European Parliament and of the Council of 25 November 2002 on waste statistics. OJ L $332,9.12 .2002,1-36$.

6. European Parliament and Council Directive 94/62/EC of 20 December 1994 on packaging and packaging waste. OJ L 365, 31.12.1994, 10-23. 
7. Directive (EU) $2015 / 720$ of the European Parliament and of the Council of 29 April 2015 amending Directive 94/62/EC as regards reducing the consumption of lightweight plastic carrier bags. OJ L 115, 6.5.2015, 11-15.

8. Directive 2000/53/EC of the European Parliament and of the Council of 18 September 2000 on end-of life vehicles. OJ L 269, 21.10.2000, 34-43.

9. Directive 2005/64/EC of the European Parliament and of the Council of 26 October 2005 on the type-approval of motor vehicles with regard to their reusability, recyclability and recoverability and amending Council Directive 70/156/EEC. OJ L 310, 25.11.2005, 10-27.

10. Directive 2006/66/EC of the European Parliament and of the Council of 6 September 2006 on batteries and accumulators and waste batteries and accumulators. OJ L 266, 26.9.2006, 1-14.

11. Directive 2012/19/EU of the European Parliament and of the Council of 4 July 2012 on waste electrical and electronic equipment. OJ L 197, 24.7.2012, 38-71.

12. Council Directive $86 / 278 /$ EEC of 12 June 1986 on the protection of the environment, and in particular of the soil, when sewage sludge is used in agriculture. OJ L 181, 4.7.1986, 6-12.

13. Directive 2006/21/EC of the European Parliament and of the Council of 15 March 2006 on the management of waste from extractive industries. OJ L 102, 11.4.2006, 15-34.

14. Directive 2000/59/EC of the European Parliament and of the Council of 27 November 2000 on port reception facilities for ship-generated waste and cargo residues. OJ L 332, 28.12.2000, 81-90.

15. The Basel Convention on the Control of Transboundary Movements of Hazardous Wastes and Their Disposal (1999). Council Decision 93/98/EEC of 1 February 1993 on the conclusion, on behalf of the Community, of the Convention on the control of transboundary movements of hazardous wastes and their disposal (Basel Convention). OJ L 39, 16.2.1993, 1-2.

16. Council Regulation (Euratom) No $1493 / 93$ of 8 June 1993 on shipments of radioactive substances between Member States. OJ L 148, 19.6.1993, 1-7. Council Directive 2006/117/Euratom of 20 November 2006 on the supervision and control of shipments of radioactive waste and spent fuel. OJ L 337, 5.12.2006, 21-32.

17. Council Directive 2011/70/Euratom of 19 July 2011 establishing a Community framework for the responsible and safe management of spent fuel and radioactive waste. OJ L 199, 2.8.2011, 48-56.

18. Langlet, D. \& Said Mahmoudi (2016). EU Environmental Law and Policy. 1st ed. Oxford University Press, 284.

19. European Commission: Circular Economy. Available at: http://ec.europa.eu/environment/circular-economy/index_en.htm.

20. Association Agreement between the European Union and its Member States, of the one part, and Ukraine, of the other part. OJ L 161, 29.5.2014, 3-2137.

21. Ladychenko, V., Yara, O., Golovko, L. \& Serediuk V. (2019). Groundwater Management in Ukraine and the EU. European Journal of Sustainable Development. 8(1): 31-39.

22. Order of the Government of November 8, 2017 No. 820-p On Approval of the National Strategy for Waste Management in Ukraine until 2030. Available at: https:// www.kmu.gov.ua/ua/npas/250431699.

23. On Waste (1998): Law of Ukraine. Bulletin of the Verkhovna Rada of Ukraine, 36-37: 242.

24. Ladychenko, V. \& Golovko, L. (2017). Implementation of European Environmental Policy in Ukraine: Problems and Prospects. European Journal of Sustainable Development, 6 (3): 333-339.

25. Ladychenko, V., Yara, O., Uliutina, O. \& Golovko, L. (2019). Environmental Liability in Ukraine and the EU. European Journal of Sustainable Development, 8 (2): 261-267. 
26. Yara, O., Uliutina, O., Golovko, L. \& Andrushchenko, L. (2018). The EU Water Framework Directive: Challenges and Prospects for Implementation in Ukraine. European Journal of Sustainable Development, 7 (2): 175-182.
27. Ladychenko, V. \& Golovko, L. (2018). The Right of Access to Environmental Information in Ukraine and the EU European Journal of Sustainable Development, 7 (3): 455-459.

\section{Іржі Зіха \& Л.О. Головко (2019). Законодавство Європейського Союзу про комунальні відходи та його відображення в Угоді про асоціацію між Україною та ЄС. Право. Людина. Довкілля. 10(4): 180-186. https://doi.org/10.31548/law2019.04.022.}

Анотація. Підписавши Угоду про асоціацію з європейським Союзом 27 червня 2014 p. Україна продовжила прочес адаптації вітчизняного законодавства у сфері поводження з відходами до європейських стандартів. Згідно з додатком XXX до глави 6 Угоди про асоціацію, Україна повинна виконувати наступні три директиви: Директива 2008/98 / ЄС Європейського парламенту та Ради від 19 листопада 2008 року про відходи та скасування деяких директив; Директива Ради 1999 / З1ЕС від 26 квітня 1999 року про захоронення відходів та Директива 2006/21 / ЄС Європейського парламенту та Ради від 15 березня 2006 року про управління відходами видобувних підприємств. Переваги для України після підписання Угоди про асоціацію є безумовними, але важливішим є виконання ії положень.

Беручи участь у спільному українсько-чеському науково-дослідному проекті «Екологічна Політика ЄС у срері поводження з твердими побутовими відходами та ї імплементація в Україні та Чехії», ми дослідили законодавство ЄС у срері поводження з відходами, його принципи та стандарти. Досліджено стан адаптації українського законодавства до вимог Європейського Союзу у сфері поводження з відходами. Виявлено деякі прогалини в українському законодавстві.

Ключові слова: політика ЄС у срері поводження з відходами, право ЄС, поводження з відходами, комунальні відходи, адаптація законодавства до законодавства $\in C$ 